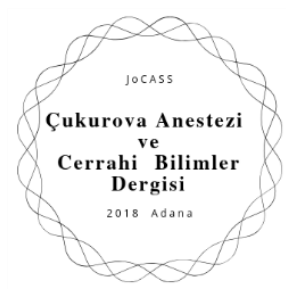

\title{
THE RELATIONSHIP BETWEEN PERSISTENT PAIN AND TACTILE SENSORY AND PAIN PRESSURE THRESHOLDS IN POSTMASTECTOMY BREAST CANCER PATIENTS: A PRELIMINARY REPORT POSTMASTEKTOMI MEME KANSERLI HASTALARDA PERSISTAN AĞRI ILE TAKTIL DUYUSAL VE AĞRI BASINCI EŞIKLERI ARASINDAKI ILIŞKI: BIR ÖN RAPOR
}

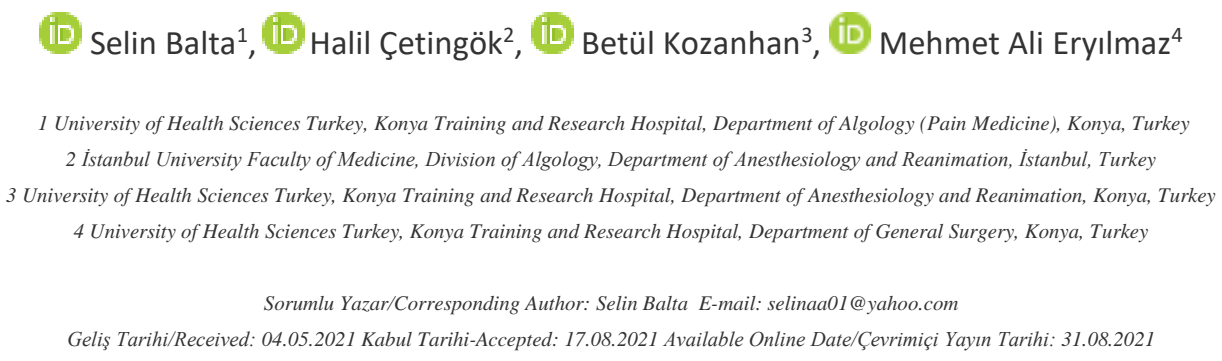

Abstract

Introduction: Persistent postmastectomy pain is common among breast cancer patients. The relationship of persistent postmastectomy pain (PPP) with sensory loss and increased pain sensitization remains unclear. In this study, we investigated the relationship between PPP and tactile sensory thresholds and pain pressure thresholds in postmastectomy breast cancer patients. Materials and Methods: Patients were divided into two groups according to the presence and absence of PPP. On both the operated and non-operated sides, pain pressure thresholds (breast, arm, and forearm) were assessed using an algometer, and tactile sensory thresholds (scar region, breast upper outer quadrant, axillary region, median cutaneous nerve and intercostobrachial nerve regions, forearm, and hand) were measured using the Semmes-Weinstein monofilament test. The differences between the operated and nonoperated sides were calculated to investigate whether there was a relation between pain sensitivity and sensory loss and PPP. Results: PPP was detected in $31(64.6 \%)$ of 48 patients. There was a statistically significant difference in the tactile sensory thresholds and pain pressure thresholds of the operated and non-operated sides $(P<0.001)$. There was no statistically significant difference between the pain pressure thresholds and tactile sensory thresholds of the groups with and without PPP. There was a weak positive correlation between the mean pain intensity and side to side difference in tactile sensory thresholds measured from the axillary region $(P=0.046, r=0.289)$.

Conclusion: Axillary region sensorial loss and PPP may be linked in postmastectomy cancer patients. Pain sensitization and loss of sensation do not seem to be associated with PPP.

Keywords: Persistent postmastectomy pain syndrome, tactile sensory threshold, pain pressure threshold, pain sensitization, sensorial deficit 
Öz

Giriş: Persistan postmastektomi ağrısı meme kanseri hastaları arasında yaygındır. Persistan postmastektomi ağrısının duyusal kayıp ve artan ağı duyarııı̆ı ile ilişkisi belirsizliğini korumaktadır. Bu çalışmada postmastektomi meme kanseri hastalarında persistan postmastektomi ağrısı ile taktil duyusal eşikler ve ağıı basıncı eşikleri arasındaki ilişkiyi araştırdık.

Gereç ve Yöntemler: Hastalar persistan postmastektomi ağrısı varlığına ve yokluğuna göre iki gruba ayrıldı. Hem opere ve nonopere taraflardaki ağrı basıncı eşikleri (meme, kol ve önkol) bir algometre cihazılla, taktil duyusal eşikler ise (skar bölgesi, meme üst dış kadran, aksiller bölge, median kutanöz sinir ve interkostobrakiyal sinir bölgeleri, önkol ve el) Semmes - Weinstein monofilaman testiyle ölçüldü. Opere ve nonopere taraflar arasındaki farklar hesaplanarak, ağrı duyarlıığı ve duyusal kayıp ile PPP arasında ilişki olup olmadığı araştıııldı.

Bulgular: Çalışmaya 48 hasta dahil edildi, hastaların 31 'inde $(\% 64,6)$ persistan postmastektomi ağrısı saptandı. Opere ve nonopere tarafların dokunsal duyusal eşikleri ve ağıı basıncı eşikleri arasında istatistiksel olarak anlamlı bir fark vardı $(P<0.001)$. Grupların ağıı basıncı eşikleri ile dokunsal duyusal eşikleri arasında istatistiksel olarak anlamlı bir fark yoktu. Ortalama ağrı şiddeti ile aksilller bölgeden ölçülen opere ve nonopere tarafların taktil duyusal eşik farkları arasında zayıf düzeyde pozitif korelasyon saptandı ( $P=$ $0.046, r=0.289$ ).

Sonuç: Aksiller bölgedeki duyusal kayıp ve persistan postmastektomi ağrısı, postmastektomi kanser hastalarında ilişkili olabilir. Ağrı duyarılığı ve duyu kaybı ise persistan postmastektomi ağrısı ile ilişkili görünmemektedir.

Anahtar Kelimeler: Persistan postmastektomi ağıı sendromu, taktil duyusal eşik, ağrı basınç eşiği, ağrı duyarııı̆ı, duyusal kayıp

\section{Introduction}

Breast cancer is the most common type of cancer in women. Worldwide, the incidence of breast cancer is $27-94$ per $100,000^{1}$. PPP defined by the International Association for the Study of Pain as chronic pain in the anterior aspect of the thorax, axilla, and/or upper half of the arm beginning after a mastectomy and persisting for more than 3 months after the surgery ${ }^{2}$. According to the International Association for Study of Pain, the prevalence of persistent postmastectomy pain (PPP) in breast cancer patients is $40-89 \%{ }^{3}$. PPP in breast cancer can be moderate-to-severe and have a negative impact on quality of life $(\mathrm{QoL})^{4}$. Gottrup et al. investigated the potential association of PPP with sensory changes and pain sensitization in 15 breast cancer patients with pain and 11 breast cancer patients without pain ${ }^{5}$. They found that thermal sensory thresholds were higher on the operated side in both groups and that pain sensitization was higher in the group with pain. Andersen et al. assessed the relationship between sensory function and PPP, following patients from the preoperative period to postoperative 1 year ${ }^{6}$. They showed that areas of increased hypoesthesia were related to pain at rest and that pain developed with movement. In the same study, movement-related pain on the operated and nonoperated sides differed due to a difference in pain pressure thresholds (PPTs). In addition, they revealed that sensorial thresholds and PPTs are related with sensory impairment.

In the literature, the findings of studies on the relationship between nerve damage and PPP are contradictory ${ }^{5-7}$. In our study, we aimed to evaluate the relationship between the presence, intensity, and impact of PPP and PPTs and tactile sensory thresholds (TSTs).

\section{Materials and Methods}

This cross-sectional prospective study was conducted in accordance with the Declaration of Helsinki. This study was carried out in the University of Health sciences, Konya Training and Research Hospital between August 2019 and October 2020. Ethical approval was received from the ethics committee of the medical faculty 
of Necmettin Erbakan University (IRB approval number: 2019/1995; date: 7 July 2019). The written informed consent obtained from all the participants.

Volunteer patients aged 18-80 years who had been diagnosed with breast cancer and presented for a routine follow-up 3-60 months postsurgery in the general surgery breast unit were included in the study. Patients with a history of bilateral breast cancer, cancer recurrence, reconstructive breast surgery, cognitive impairment, thoracic and/or lower cervical radiculopathy, metastasis, and breast reconstructive surgery were excluded. In addition, those with severe psychiatric diseases, central nervous system diseases, progressive neurological diseases, upper extremity lymphedema, frozen shoulder, noncancerous chronic pain syndrome were excluded. Finally, patients who were pregnant and patients who had used gabapentinoids, antidepressant drugs, or painkillers within the last $24 \mathrm{~h}$ were excluded from the study.

Data were obtained on patient age, cancer side and stage, surgery time, history of chemotherapy and radiotherapy, pain area (breast, axillary region, and arm), and pain treatment history. The Brief Pain Inventory Short Form (BPI SF) was used to assess PPP severity and PPP-related effects. Also, patients completed the European Organization for Research and Treatment of Cancer and Quality of Life Group BR-23 (EORT QLQ BR-23) questionnaire.

The BPI SF is an easy-to-understand pain assessment questionnaire that the participant can complete unaided. The BPI SF consists of two subsections, one which evaluates pain intensity and the other which assesses pain-related effects. Using the BPI $\mathrm{SF}$, the patients provided information about their pain levels in the previous $24-\mathrm{h}$ period, average pain levels during this $24-\mathrm{h}$ period, and current pain levels. A 0-10 numerical rating scale was used to rate pain severity, where 0 denoted "no pain" and " 10 " denoted "the most severe pain you have experienced." To assess the impact of pain on functional skills, using a 0-10 numerical scale, the patients were asked to rate the effect of pain on the following factors: working life, daily living activities, emotional state, mood, sleeping, walking capacity, and social relationships ${ }^{8}$. We used the threshold values of pain severity determined by Serlin et al. ${ }^{9}$.

In our study group, we examined TSTs and PPTs of both the operated and non-operated sides. To assess PPTs, using an algometer, a simple, routine pain threshold measuring instrument, PPTs in the following areas were assessed: scar, arm (deltoid midpoint), and forearm (lateral epicondyle $2 \mathrm{~cm}$ distally). The investigator placed the algometer on the site to be examined and pressed against the site in a vertical direction while increasing the force at a constant rate of $1 \mathrm{~kg} / \mathrm{cm}^{2}$. The participants were instructed to express pain either by saying stop or by raising their hands when they felt slight discomfort. The algologist gradually increased the pressure by 1 $\mathrm{kg} / \mathrm{cm}^{2} / \mathrm{s}$ until the participants felt the first sensation of pain (PPT). A maximum pressure of $22 \mathrm{~kg} / \mathrm{cm}^{2}$ was applied for all the participants.

The EORT QLQ BR-23 questionnaire has 23 items, which include functional scales (body image, sexual functioning, sexual enjoyment, and hopes) and symptom scales (systemic therapy side effects, breastrelated pain/skin problems-/disorders, armrelated pain/problems/-dysfunction symptoms, and hair loss). The breast symptom and arm symptom subscale scores are calculated. Higher scores on the functional scales indicate better overall QoL, whereas higher scores on the symptom's scales indicate poorer $\mathrm{QoL}^{10}$.

To evaluate TSTs, the Semmel-Weinstein test was used. The researcher started with the smallest monofilament and applied it to the largest filament in the correct order, but the researcher stopped the test when the smallest monofilament tested was detected by the patient and recorded the value. Using this screening tool, TSTs of the scar region, upper outer quadrant of the breast, axillary 
region, intercostobrachial nerve region, medial cutaneous nerve region, and forearm and hand on both the operated and nonoperated sides were assessed. In addition, side to side differences in PPTs were calculated by extracting the operated side PPTs from the non-operated side PPTs to reveal whether pain sensitivity may be related to PPP. Side to side differences in TSTs were calculated by extracting nonoperated side TSTs from operated-side TSTs to reveal whether sensory loss may be related to PPP.

Patients were divided into two groups according to the presence and absence of
PPP to investigate whether there is a relationship presence of pain with side to side differences of the PPTs and TSTs.

A post hoc sample size analysis was performed after the finalization of the study. A power analysis was conducted using the G-power software package, Version 3.1.6 (Franz Faul, Kiel University, Kiel, Germany) power analysis was used. Fortyeight patients were included in the final analysis. The power of the study was 0.99 , with an effect size of 0.71 and level of 0.05 . The statistical analyses were performed using SPSS version 20.0 (IBM Corp., Armonk, NY).
Patients 3-60 months after breast cancer surgery $(n=93)$

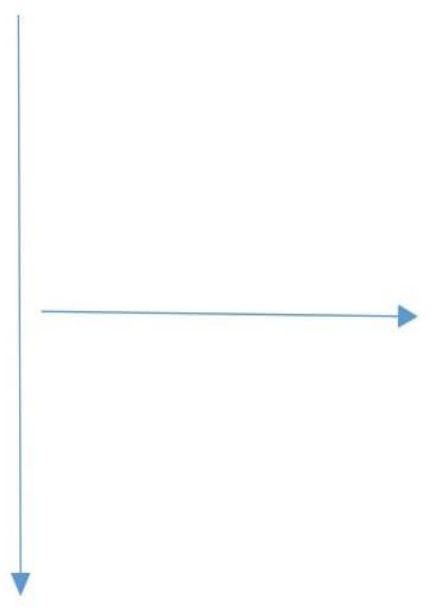

Refusing to participate $(n=23)$,

Breast reconstruction $(n=5)$,

Use of antidepressants $(n=4)$,

Cancer recurrence $(n=2)$,

Bilateral breast cancer $(n=1)$ were excluded.

48 patients included in the study

Figure 1: Flowchart 
There were no missing data. The ShapiroWilk test was used to evaluate the distribution of the data. Descriptive data, with frequencies $(n)$ and percentages $(\%)$ are presented for categorical variables. For normally distributed numerical data, mean (standard deviation) is presented, together with their $95 \%$ confidence intervals (CIs).

For non-normally distributed numeric data, minimum-maximum values, together with their $95 \%$ CIs, are presented. A chi-square test was used to compare categorical variables between independent groups. A $T$ test or Mann-Whitney $U$ test was used to compare numerical data between independent groups, depending on whether the data were normally distributed or not. The relationship between the numerical data was evaluated using Spearman's correlation analysis. A $P$ value of $<0.05$ was considered statistically significant.

\section{Results}

Forty-eight breast cancer patients with a mean age of $51.53( \pm 8.08)$ years in a postoperative period of 11.0 (3.0-38.0) months were included in the study (Fig. 1). Cancer staging in the preoperative period was stage 1 in $20(41.7 \%)$ patients, stage 2 in $17(35.4 \%)$ patients, and stage 3 in 11 $(22.3 \%)$ patients. In total, $44(91.7 \%)$ patients had received chemotherapy, and 40 $(83.3 \%)$ patients had received radiotherapy. Thirty-one $(64.6 \%)$ patients had PPP, the painful area was in the breast in $9(29.03 \%)$ patients; axillary region in $8(25.1 \%)$ patients; arm in $6(19.35 \%)$ patients; and breast together with axillary region and arm areas in $8(25.1 \%)$ patients. Based on the cut-off values determined by Serlin for pain severity, 21 (43.8\%) patients had moderateto-severe pain. The mean pain intensity was $3.75 \pm 2.98$ [2.67-4.82]. The BPI SF pain interference score was $1.28 \quad(0.0-7.45)$ [1.26-3.02].

The patients were divided into two groups that with PPP $(n=31)$ and without PPP (n $=17$ ). There was no difference in age between the groups $(z=0.313, P=0.754)$. There was no difference in a history of chemotherapy, radiotherapy, lymph node dissection type, or surgery type between groups $\left(\chi^{2}=0.406, P=0.607 ; \chi^{2}=0.180\right.$, $P=0.595 ; \chi^{2}=0.603, P=0.436$; and $\chi^{2}=$ $0.091, P=0.763$, respectively).

There was a statistically significant difference in the TSTs (Table 1) and PPTs (Table 2) of the operated and nonoperated sides. There was no statistically significant difference in the TSTs and PPTs of the operated and nonoperated sides between groups (Table 3 ).

There was a weak positive correlation between the mean PPP intensity and side to side differences in the TSTs of the axilla ( $P$ $=0.046, r=0.289)$. There was no statistically significant correlation between the mean PPP intensity and side to side differences in the TSTs of the hand, forearm, median cutaneous nerve region, intercostobrachial nerve region, breast upper outer quadrant, and scar regions or the PPTs of the scar region, arm, and forearm areas $(P=0.837, r=-0.030 ; P=$ $0.672, r=0.063 ; P=0.705, r=0.056 ; P=$ $0.059, r=0.691 ; P=0.586, r=0.081 ; P=$ $0.439, r=-0.114 ; P=0.949, r=0.010 ; P=$ $0.870, r=0.024$; and $P=0.535, r=0.092$, respectively).

There was no statistically significant correlation between the pain interference score and side to side differences in the TSTs of the hand, forearm, median cutaneous nerve region, intercostobrachial nerve region, axilla, upper outer quadrant of the breast, and scar region, as well as side to side differences in the PPTs of the scar region, arm, and forearm $(P=0.990, r=$ $0.002 ; P=0.569, r=0.084 ; P=0.775, r=$ $0.042 ; P=0.901, r=0.018 ; P=0.115, r=$ $0.230 ; P=0.519, r=0.095 ; P=0.767, r=$ -0.004; $P=0.448, r=0.103 ; P=0.462, r=$ $0.109 ;$ and $P=0.141, \quad r=0.216$, respectively). 
Table 1. Tactile sensory thresholds of different regions of the operated and nonoperated sides

\begin{tabular}{llllll}
\hline Area & & & \multicolumn{2}{c}{ Tactile sensory thresholds } & \\
& & Median & Min-Max & $95 \%$ C.I. & P \\
\hline Hand & Operated & 2.69 & $2.56-4.31$ & $2.76-3.17$ & 0.005 \\
& Healthy & 2.56 & $2.56-4.31$ & $2.67-3.03$ & \\
Arm & Operated & 2.83 & $2.56-4.31$ & $2.96-3.33$ & 0.007 \\
& Healthy & 2.83 & $2.56-4.31$ & $2.89-3.24$ & \\
Medial cutaneous & Operated & 3.61 & $2.82-4.56$ & $3.35-3.71$ & 0.001 \\
& Healthy & 3.22 & $2.83-4.31$ & $3.19-4.49$ & \\
Intercostobrachialis & Operated & 3.72 & $2.83-4.56$ & $3.47-3.83$ & $<0.001$ \\
& Healthy & 3.22 & $2.83-4.31$ & $3.22-3.52$ & \\
Axilla & Operated & 4.08 & $2.56-5.46$ & $3.77-4.19$ & $<0.001$ \\
& Healthy & 3.61 & $2.83-4.31$ & $3.37-3.66$ & \\
Breast upper outer quadrant & Operated & 3.84 & $2.83-4.56$ & $3.60-3.92$ & $<0.001$ \\
& Healthy & 3.61 & $2.83-4.31$ & $3.34-3.60$ & \\
Scar & Operated & 4.17 & $2.83-5.46$ & $4.07-4.48$ & $<0.001$ \\
& Healthy & 3.41 & $2.83-4.31$ & $3.34-3.62$ & \\
\hline
\end{tabular}

Table 2. Pain pressure thresholds of different regions of the operated and nonoperated sides

\begin{tabular}{llllll}
\hline Area & & \multicolumn{3}{c}{ Pain Pressure Thresholds } & \\
& & Median & Min-Max & $95 \%$ C.I. & P \\
\hline Scar & Operated & 4.50 & $2.00-20.00$ & $4.50-7.44$ & $<0.001$ \\
& Healthy & 10.00 & $4.00-20.00$ & $4.49-11.88$ & \\
\multirow{2}{*}{ Arm } & Operated & 8.50 & $4.00-20.00$ & $8.51-12.30$ & $<0.001$ \\
& Healthy & 12.00 & $6.00-20.00$ & $11.36-14.89$ & \\
\multirow{2}{*}{ Forearm } & Operated & 9.50 & $4.00-20.00$ & $9.52-13.23$ & $<0.001$ \\
& Healthy & 12.50 & $6.00-20.00$ & $12.04-15.50$ & \\
& & & & & \\
\hline
\end{tabular}


Table 3. Side differences in pain pressure thresholds and tactile sensory thresholds in the patients with and without persistent postmastectomy pain

\begin{tabular}{|c|c|c|c|c|c|c|}
\hline & \multirow[b]{2}{*}{ Area } & \multirow[b]{2}{*}{ PPP } & \multicolumn{3}{|c|}{ Side to side difference } & \multirow[b]{2}{*}{$\mathrm{P}$} \\
\hline & & & Median & Min-Max & 95\% C.I. & \\
\hline \multirow{10}{*}{ 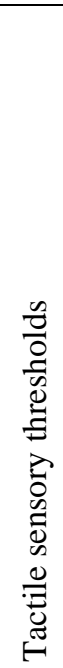 } & \multirow[t]{2}{*}{ Arm } & without & 0.00 & $0.00-2.24$ & $-0.50-0.56$ & \multirow[t]{2}{*}{0.660} \\
\hline & & with & 0.00 & $0.00-1.28$ & $0.01-0.25$ & \\
\hline & \multirow[t]{2}{*}{ Forearm } & without & 0.00 & $0.00-0.78$ & $-0.02-0.25$ & \multirow[t]{2}{*}{0.975} \\
\hline & & with & 0.00 & $0.00-0.78$ & $0.01-0.17$ & \\
\hline & \multirow[t]{2}{*}{ Medial cutanoeus } & without & 0.00 & $0.00-0.78$ & $0.01-0.34$ & \multirow[t]{2}{*}{0.641} \\
\hline & & with & 0.00 & $-0.39-1.25$ & $0.07-0.31$ & \\
\hline & \multirow[t]{2}{*}{ Intercostobrachial } & without & 0.00 & $0.00-1.34$ & $0.11-0.58$ & \multirow[t]{2}{*}{0.702} \\
\hline & & with & 0.24 & $0.00-1.25$ & $0.21-0.49$ & \\
\hline & \multirow[t]{2}{*}{ Axilla } & without & 0.23 & $0.00-2.00$ & $0.15-0.81$ & \multirow[t]{2}{*}{0.178} \\
\hline & & with & 0.47 & $-1.25-1.25$ & $0.31-0.65$ & \\
\hline & \multirow{2}{*}{$\begin{array}{l}\text { Breast upper outer } \\
\text { quadrant }\end{array}$} & without & 0.23 & $-0.23-1.29$ & $0.11-0.52$ & \multirow[t]{2}{*}{0.360} \\
\hline & & with & 0.39 & $0.00-2.26$ & $0.24-0.58$ & \\
\hline & \multirow[t]{2}{*}{ Scar } & without & 0.86 & $0.00-1.96$ & $0.54-1.21$ & \multirow[t]{2}{*}{0.364} \\
\hline \multirow{7}{*}{ 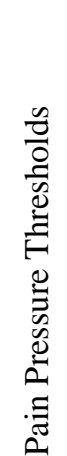 } & & with & 0.72 & $0.00-1.52$ & $0.51-0.86$ & \\
\hline & \multirow[t]{2}{*}{ Scar } & without & 3.00 & $0.00-15.00$ & $1.98-6.13$ & \multirow[t]{2}{*}{0.820} \\
\hline & & with & 3.00 & $0.00-16.00$ & $2.79-5.79$ & \\
\hline & \multirow[t]{2}{*}{ Arm } & without & 1.00 & $0.00-11.00$ & $0.63-3.96$ & \multirow[t]{2}{*}{0.891} \\
\hline & & with & 1.00 & $0.00-12.00$ & $1.19-3.52$ & \\
\hline & \multirow[t]{2}{*}{ Forearm } & without & 0.00 & $-1.00-10.00$ & $0.20-3.68$ & \multirow[t]{2}{*}{0,416} \\
\hline & & with & 1.00 & $0.00-11.00$ & $1.08-3,05$ & \\
\hline
\end{tabular}

\section{Discussion}

In line with the literature $\mathrm{e}^{3,4}$, we found that $64.6 \%$ of the patients had PPP, and $43.8 \%$ had moderate-to-severe pain. In this study, the PPTs on the operated side were lower than those on the non-operated side, and there was no correlation between side to side differences in PPTs and PPP intensity. In addition, there was no statistically significant difference in PPTs between the patients with and without PPP. Mustonen et al. showed that postmastectomy patients with neuropathic pain had lower PPTs on the affected side than the non-operated side $^{11}$. In a previous research, lower PPTs on the affected side were associated with peripheral sensitization and defined as secondary hyperalgesia ${ }^{12}$. Similar to the findings of our study, Andersen et al. ${ }^{6}$ reported no difference in PPTs of postmastectomy patients with and without pain. Fernandez-Lao et al. $^{13}$ detected no difference between operated and nonoperated sides in PPTs of the 
zygapophyseal joint (C5-C6), deltoid, second metacarpal joint, and tibialis anterior in postmastectomy cancer patients. They found a moderate negative correlation between low deltoid PPTs and axillary/shoulder pain intensity. Considering the findings of our study and those in the literature, peripheral sensitization may not be related to PPP severity.

In this study, in line with the literature ${ }^{13}$, TSTs on the operated side were higher than on the non-operated side. We found no statistically significant difference in the TSTs of those with and without PPP. In terms of side to side differences, TSTs were higher in the axillary region in the patients with PPP. There was a positive correlation between the difference in sensory thresholds between the operated and nonoperated sides in the axillary region and increased pain intensity and a negative correlation with arm symptom on QoL. Similar to the findings of our study, Vilholn et al. $^{14}$ found that thermal sensory thresholds in breast cancer patients were higher on the operated than nonoperated side after a mastectomy. In the same study, they reported that thermal sensory loss in a PPP group was higher than in a non-PPP group. In line with the literature ${ }^{6}$, in our study, hypoesthesia was common among all patients, irrespective of the presence or absence of pain. The "intact nociceptor hypothesis" has been put forward to explain hypoesthesia in postmastectomy patients ${ }^{15}$, ${ }^{16}$. Our findings suggested that tactile loss of sensation in the axillary region had a negative effect on QoL. Previous research showed that sensory re-education treatment could lead to functional gains in patients with upper extremity peripheral nerve injury and pain accompanied by upper extremity neuropathic pain ${ }^{17,} 18$. Future studies could focus on improving functionality and relieving pain severity in patients postmastectomy via sensory reeducation treatment.

Our study has some limitations. The crosssectional design of the study was a limitation. Both the presence and severity of PPP change over time. A better understanding of the relationship between sensory impairment and postmastectomy pain syndrome can be obtained by repeated measurements of pain and sensation during both the presurgery and postsurgery periods, with a long-term follow-up required. Another limitation was that the sensorial deficit was examined only via TSTs. Assessment of dynamic mechanical allodynia, hot-cold sensory thresholds, vibration thresholds could shed additional light on hyperesthesia in postmastectomy patients. Finally, there may be participant bias related to patients' willingness to participate in the study. Those with sensory problems and/or pain would have been more likely to agree to volunteer, which may have affected the study results.

There was no relationship between the presence and severity of PPP, sensory loss, and pain sensitization operated in breast cancer patients. We conclude that in patients with increased loss of sensation in the axillary region, PPP may be more severe, with negative impacts on QoL. Given the reported value of sensory reeducation programs in enhancing functionality ${ }^{17,} 18$, studies are needed to assess the potential of such programs in improving functionality and reducing pain severity in breast cancer patients with PPP.

\section{Conflict of Interest}

The authors declare that they have no conflict of interest.

Funding

None

Ethical approval

The ethics committee of the medical faculty of Necmettin Erbakan University (IRB 
approval number: 2019/1995; date: 7 July 2019).

\section{References}

1. Sancho-Garnier H, Colonna M. Breast cancer epidemiology. Presse Med. 2019; 48(10): 107684. https://doi.org/10.1016/j.lpm.2019.09.022.

2. Merskey HELP. Classification of chronic pain: Descriptions of chronic pain syndromes and definitions of pain terms. Pain Suppl. 1986; 3: 1126.

3. Marcus DA. Epidemiology of cancer pain. Curr Pain Headache Rep. 2011; 15(4): 231-4. https://doi.org/10.1007/s11916-011-0208-0.

4. Miaskowski C, Dibble SL, editors. The problem of pain in outpatients with breast cancer. Oncology nursing forum; 1995.

5. Gottrup H, Andersen J, Arendt-Nielsen L, et al. Psychophysical examination in patients with post-mastectomy pain. Pain. 2000; 87(3): 27584. https://doi.org/10.1016/S0304-3959(00)00291-8

6. Andersen KG, Duriaud HM, Kehlet H, et al. The Relationship between Sensory Loss and Persistent Pain 1 Year After Breast Cancer Surgery. J Pain. 2017; 18(9): 1129-38. https://doi.org/10.1016/j.jpain.2017.05.002

7. Warrier S, Hwang S, Koh CE, et al. Preservation or division of the intercostobrachial nerve in axillary dissection for breast cancer: metaanalysis of randomised controlled trials. Breast. 2014; 23(4): 310-6. https://doi.org/10.1016/j.breast.2014.01.014.

8. Celik EC, Yalcinkaya EY, Atamaz F, et al. Validity and reliability of a Turkish Brief Pain Inventory Short Form when used to evaluate musculoskeletal pain. Journal of back and musculoskeletal rehabilitation. 2017; 30(2): 22933. https://doi.org/10.3233/BMR-160738.

9. Serlin RC, Mendoza TR, Nakamura Y, et al. When Is Cancer Pain Mild, Moderate or Severe Grading Pain Severity by Its Interference with Function. Pain. 1995; 61(2): 277-84. https://doi.org/10.1016/0304-3959(94)00178-H.

10. Demirci S, Eser E, Ozsaran Z, et al. Validation of the Turkish versions of EORTC QLQ-C30 and BR23 modules in breast cancer patients. Asian Pac J Cancer Prev. 2011; 12(5): 1283-7.

11. Mustonen L, Vollert J, Rice ASC, et al. Sensory profiles in women with neuropathic pain after breast cancer surgery. Breast Cancer Res Treat. 2020; 182(2): 305-15. https://doi.org/10.1007/s10549-020-05681-8

12. Plinsinga ML, Brink MS, Vicenzino B, et al. Evidence of Nervous System Sensitization in
Commonly Presenting and Persistent Painful Tendinopathies: A Systematic Review. J Orthop Sports Phys Ther. 2015; 45(11): 864-75. https://doi.org/10.2519/jospt.2015.5895

13. Fernandez-Lao C, Cantarero-Villanueva I, Fernandez-De-Las-Penas C, et al. Widespread Mechanical Pain Hypersensitivity as a Sign of Central Sensitization after Breast Cancer Surgery: Comparison between Mastectomy and Lumpectomy. Pain Medicine. 2011; 12(1): 72-8. https://doi.org/10.1111/j.15264637.2010.01027.x.

14. Vilholm OJ, Cold S, Rasmussen L, et al. Sensory function and pain in a population of patients treated for breast cancer. Acta Anaesthesiol Scand. 2009; 53(6): 800-6. https://doi.org/10.1111/j.13996576.2009.01938.x.

15. Wijayasinghe N, Andersen KG, Kehlet $\mathrm{H}$. Analgesic and Sensory Effects of the Pecs Local Anesthetic Block in Patients with Persistent Pain after Breast Cancer Surgery: A Pilot Study. Pain Pract. 2017; 17(2): 185-91. https://doi.org/10.1111/papr.12423.

16. Wijayasinghe N, Duriaud HM, Kehlet H, et al. Ultrasound-Guided Intercostobrachial Nerve Blockade in Patients with Persistent Pain after Breast Cancer Surgery: A Pilot Study. Pain Physician. 2016; 19(2): 309-18.

17. Miller LK, Chester R, Jerosch-Herold C. Effects of sensory reeducation programs on functional hand sensibility after median and ulnar repair: a systematic review. J Hand Ther. 2012; 25(3): 297-306. https://doi.org/10.1016/j.jht.2012.04.001.

18. Lewis JS, Coales K, Hall J, et al. 'Now you see it, now you do not': sensory-motor re-education in complex regional pain syndrome. Hand therapy. $2011 ; 16(2): 29-38$. https://doi.org/ 10.1258/ht.2011.011005. 